\title{
SOURCES AND DIAGENETIC ALTERATION OF ORGANIC MATTER IN COASTAL WATERS AT THE VICINITY OF DAR ES SALAAM, TANZANIA
}

\author{
ANN Muzuka \\ Institute of Marine Sciences, University of Dar es Salaam, \\ P.O. Box 668, Zanzibar, Tanzania
}

\begin{abstract}
The stable isotope compositions of organic carbon (OC) and nitrogen, contents of $O C$ and nitrogen, and $C / N$ ratios for four short cores, which were recovered from Msasani Bay (WO 57), off Msimbazi River (WO 76) and Dar es salaam harbour (WO 62 and WO 74), are used to document temporal variation in the sources and diagenetic alteration of organic matter $(O M)$. The $\delta^{15} N$ and $\delta^{13} C$ values at sites WO 57, WO 62 and WO 74 show a trend of down-core decrease to the base of the core, and such a down-core trend could be related to diagenetic loss of compounds enriched in ${ }^{13} \mathrm{C}$ and ${ }^{15} \mathrm{~N}$. At site WO 76, the $\delta^{15} \mathrm{~N}$ values show a slight down-core increase, while $\delta^{13} C$ values show two zones that are depleted in ${ }^{13} C$. These two zones correspond to black-greasy layers that were observed during sampling, and low $\delta^{13} C$ values probably is an indication that the material was derived from the continent. Furthermore, these two zones have elevated values of $O C$, nitrogen and $C / N$ ratios. The stable isotopes of $O C$ and nitrogen show inter-sites differences with enrichment in $15 \mathrm{~N}$ in the following order: $W O$ $57<$ WO $74<$ WO $62<$ WO 76. A similar inter-core difference is observable for the ${ }^{13} C$, but the enrichment show a reversed order. The inter-site differences in ${ }^{13} \mathrm{C}$ and ${ }^{15} \mathrm{~N}$ could be related to the sources of OM. In the Msasani Bay the material is derived from seagrasses while in the Dar es salaam harbour and Msimbazi micro-bay, large proportion is derived from the continent. Other parameters of $O C$, nitrogen and $C / N$ ratios for these three sites show a slight down-core decrease to the base of the core, probably the result of diagenetic alteration of $O M$. Highest contents of $O C$ and nitrogen are observable at site $W O$ 62 owing to preferential preservation of OM due to high input of more refractory material derived from the continent and lack of tidal flushing.
\end{abstract}




\section{INTRODUCTION}

Early diagenetic alteration of organic matter $(\mathrm{OM})$ plays a major role in mineral re-cycling as the process leads to the release of both inorganic and organic compounds such as nitrate, amino acids and carbohydrate (Froelich $e t$ al. 1979, Henrichs 1992). Also early diagenetic alteration of OM releases $\mathrm{CO}_{2}$ and nitrogen (generated during denitrification) to the atmosphere. Since these gases are among the greenhouse gases that play part in climatic changes (Watson et al. 1990, Flückiger et al. 1999), information on diagenetic change may help in better understanding global climatic changes. High resolution of diagenetic alteration of $\mathrm{OM}$ is expected to be documented in areas where the rate of supply of labile OM to the sea floor is high. Such areas include shallow coastal marine environments, and areas experiencing coastal upwelling like the Arabian Sea and off the Somali coast where deposition of large quantity of labile OM is a result of high primary productivity. Deposition of labile organic material could also be a result of anthropogenic input of nitrate rich material such as raw sewage and agricultural fertilizer to coastal waters. In such areas, diatom bloom is common and leads to high deposition of labile OM.

Resistance of organic material derived from various sources towards diagenetic alteration in marine environment differs, with material derived from terrestrial environment being relatively more resistant (Tissot 1984, Meyers 1994). Because of this, it is important to delineate sources and estimate their relative contribution prior to establishing diagenetic evolution of $\mathrm{OM}$. There are several methods that can be used to document various sources of organic material in the marine sediments including the stable isotope compositions of organic carbon (OC) and nitrogen, and lignin concentration. The stable isotope compositions of $\mathrm{OC}$ and nitrogen in particular have been used successfully in the marine environment for identifying extent of sewage and other terrestrial organic material in many parts of the world (Peters et al. 1978, Sweeney \& Kaplan 1980, Sweeney et al. 1980, Macko 1983, Anderson et al. 1992, Muzuka 1999a). However, the stable isotopes of OC and nitrogen are useful only when the isotopic compositions of various sources are distinct. In an environment like Tanzania, where large part of the country is covered by savannah vegetation, contribution of $\mathrm{C}_{4}$ plants that have a mean value of $-12 \%$ may not be easily distinguished from that of macro-algae and seagrasses (Behrens \& Frishman 1971, Deines 1980, Fry \& Sherr 1984, Gearing 1988). The use of other parameters such as the $\mathrm{C} / \mathrm{N}$ ratios in combination with the stable isotope compositions of $\mathrm{OC}$ and nitrogen may be an additional tool that may help in delineating terrestrial and marine sources (Meyers 1994).

The amount of organic material preserved in the marine sediments in conjunction with the stable isotope compositions of OC may sometimes be an indicator of the level of pollution in lacustrine and coastal waters. For example, in heavily polluted lacustrine and coastal marine zones, the contents and isotopic compositions of $\mathrm{OC}$ and nitrogen have been observed to be higher 
than unimpacted ones (Schelske \& Hodell 1995). Thus, the contents of OM and nitrogen may provide a first order assessment of human impact to the aquatic environment.

In Tanzania few studies have been conducted to evaluate relative proportions of organic material derived from various environments (Muzuka 1999b). All available work provide spatial variation in the relative proportion of organic material derived from various sources. Information on temporal variations in the sources of organic material to the coastal waters is lacking. Furthermore, the extent of diagenetic alteration of OM in the Tanzanian coastal waters is also lacking.

The present study intended to document early diagenetic evolution of OM and temporal variations in input of OM in the Tanzanian coastal waters. Specifically, the study sought to establish various sources of OM and estimate the relative contribution of each source, and assess how diagenetic processes have altered recently deposited OM. To achieve these objectives, the stable isotope compositions of $\mathrm{OC}$, and contents of $\mathrm{OC}$ and nitrogen of four short cores were used.

\section{METHODS}

Four sediment cores used in the present work were recovered off the Dar es salaam city (Fig. 1). Three out of the four cores, are located in the Msasani Bay, at the Dar es salaam Harbour entrance and off the Msimbazi river (Fig. 1), were collected by divers who hammered PVC into the sediments. The fourth one was collected within the Dar es salaam harbour using a small gravity corer. Positioning of sampling locations was achieved with the use of portable global positioning system (GPS). All cores were frozen within 12 hours of collection until processing. Cores were subsampled every $2 \mathrm{~cm}$ with each sample representing a thickness of $1 \mathrm{~cm}$. All samples were dried at a temperature of $60^{\circ} \mathrm{C}$, and ground to a fine powder prior to analysis. 


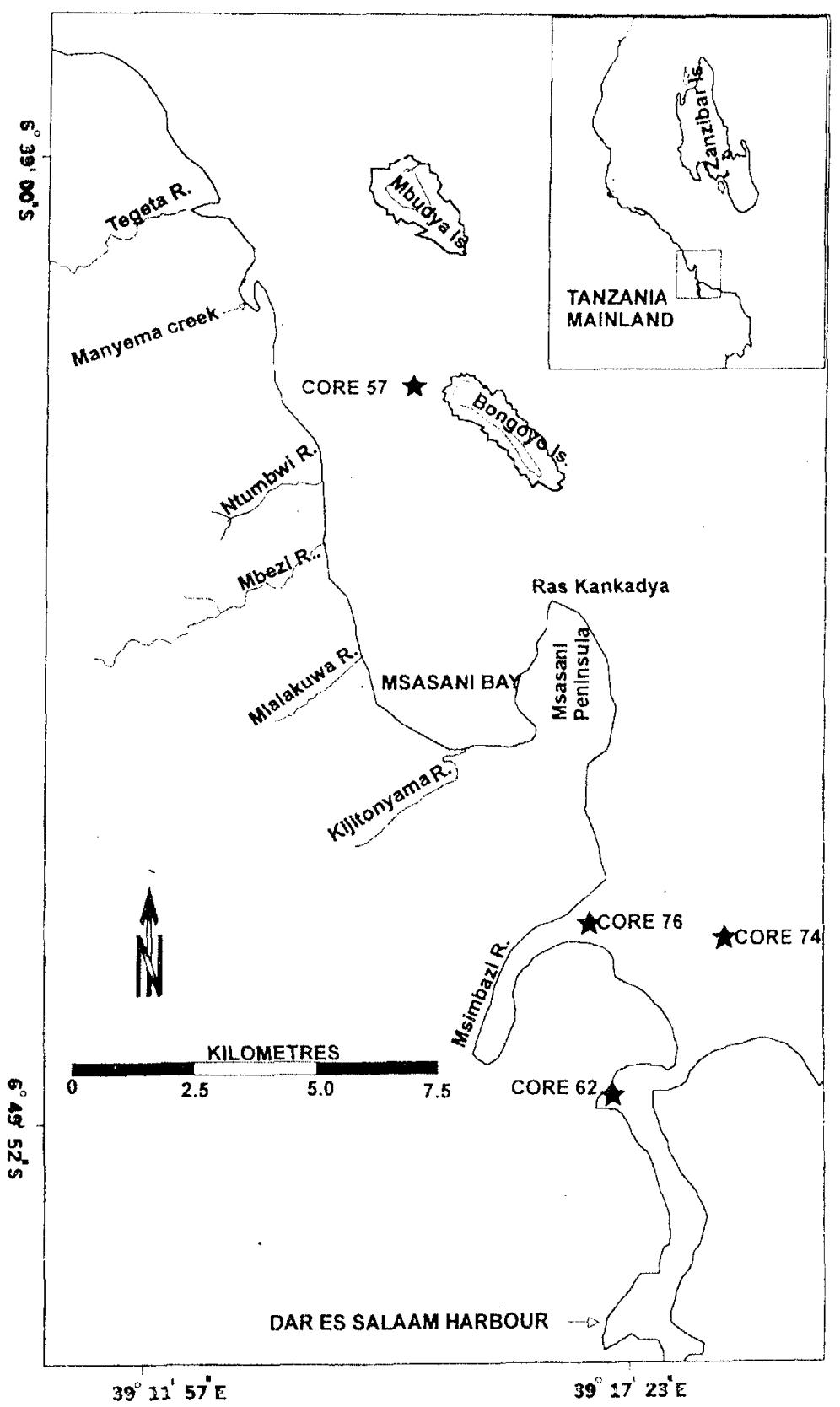

Fig. 1: A map showing study area and location of sampling sites. Sites in the text are abbreviated as WO followed by a number e.g. Core $57=$ WO 57 
Determination of stable isotope compositions and contents of sedimentary OC and nitrogen was performed at the Department of Archaeology, University of Cape Town using a FINGAN MAT mass spectrometer coupled to a $\mathrm{C}$ - $\mathrm{H}$ $\mathrm{N}$ analyser. A C-H-N analyser was used to determine contents of total carbon, residue $\mathrm{OC}$ and total nitrogen. Aliquot earmarked for the determination of residue $\mathrm{OC}$, nitrogen and stable isotope compositions of $\mathrm{OC}$ and nitrogen were first acidified using $1 \mathrm{M} \mathrm{HCl}$. During analysis atropine and nasturtium were used as internal standards. Atropine, which has a carbon content of $70.56 \%$ and nitrogen content of $4.84 \%$, was used as internal standard for the contents of $\mathrm{OC}$ and nitrogen while nasturtium, with isotope compositions of $6.58 \%$ for ${ }^{15} \mathrm{~N}$ and $-29.65 \%$ for ${ }^{13} \mathrm{C}$, was used as in-house standard for the stable isotopes of $\mathrm{OC}$ and nitrogen. The stable isotopes of $\mathrm{OC}$ and nitrogen are reported in $\delta$-notation relative to V-PDB (Coplen 1995) and atmospheric nitrogen, respectively.

\section{RESULTS}

A general trend of downcore decrease from the top to the base of these cores in the $\delta^{13} \mathrm{C}$ and $\delta^{15} \mathrm{~N}$ values is observable for three cores (WO 57, WO 62 , and WO 74) (Fig. 2). At site WO 76, downcore distribution of $\delta^{13} \mathrm{C}$ and $\delta^{15} \mathrm{~N}$ values show a dissimilar trend. Whereas the OC stable isotope values show two zones that are depleted in ${ }^{13} \mathrm{C}$ which correspond to dark-greasy layers that were observed during sampling, the $\delta^{15} \mathrm{~N}$ values show a slight downcore increase with no differences between light and dark-greasy layers (Fig. 2).

The average values for all cores (Table 1) display inter-core differences, with enrichment in ${ }^{13} \mathrm{C}$ in the following order WO $76<$ WO $62<$ WO $74<$ WO 57 (Fig. 2). Similarly, the nitrogen stable isotope compositions show inter-site differences, but with a reversed order i.e. WO $57<$ WO $74<$ WO $62<$ WO 76 relative to ${ }^{13} \mathrm{C}$ (Fig. 3). None of the stable isotope compositions of $\mathrm{OC}$ and nitrogen show any corresponding correlation with water depth (Fig. 1). 




Fig. 2: Down-core variations in the table isotope compositions of organi carbon for all cores used in this study. Shaded areas represent zones where black-grey layers were observed. Inter-core differences are also displayed 


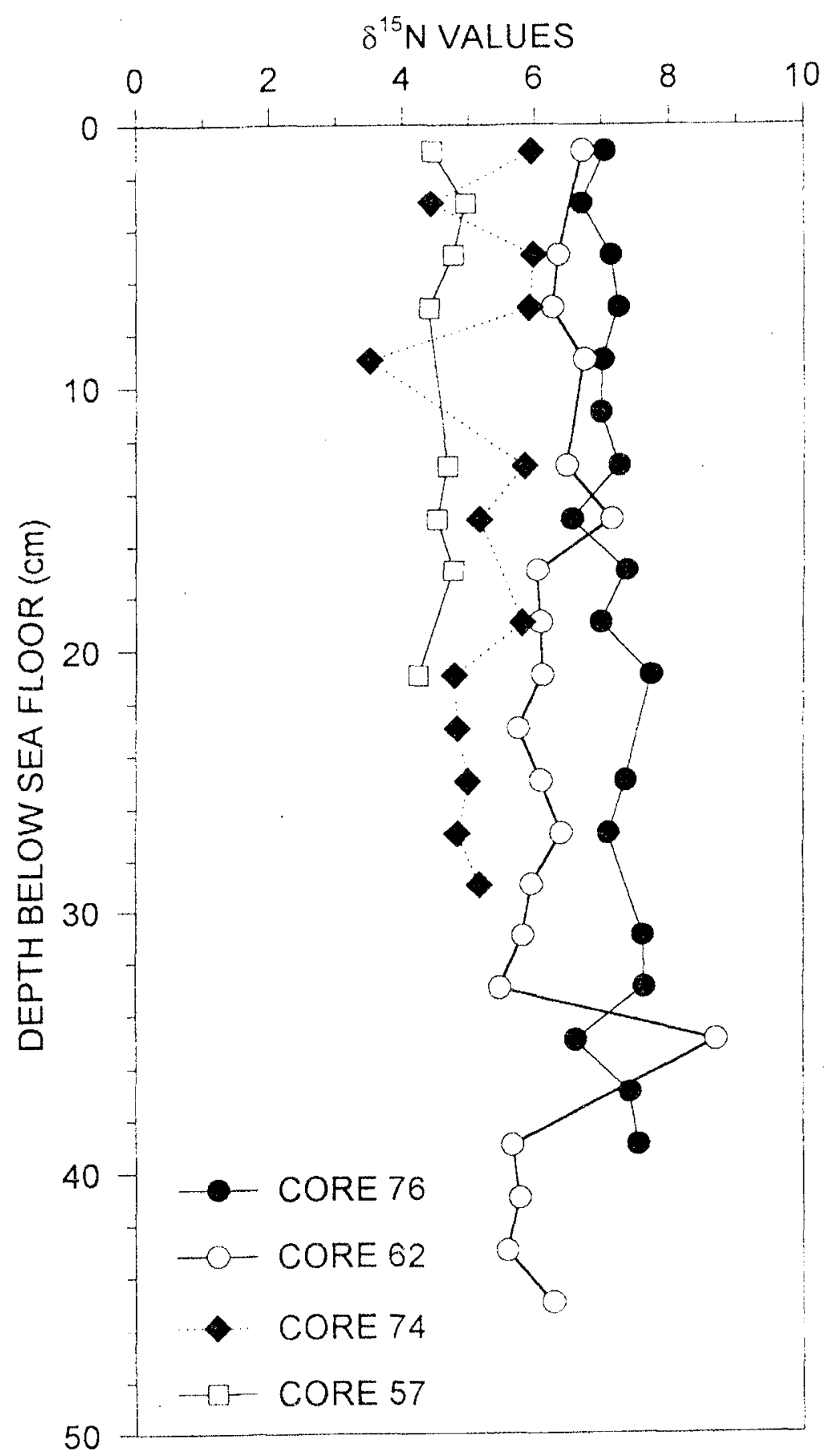

Fig. 3: Temporal variations and inter-sites relationship of nitrogen stable isotopes 
Highest nitrogen and OC contents are observable at Site WO 62 with a general downcore decrease, and a spike of higher contents being observable at approximately $32 \mathrm{~cm}$ (Fig. 4 and 5). The contents of $\mathrm{OC}$ and nitrogen for the remaining sites are low and show a slight downcore decrease to the base of the core (Figs. 4 and 5). Layers depleted in ${ }^{13} \mathrm{C}$ for core 76 are slightly enriched in nitrogen and $\mathrm{OC}$ (Figs 4 and 5) and are associated with elevated $\mathrm{C} / \mathrm{N}$ ratio values (Fig. 6). The $\mathrm{C} / \mathrm{N}$ ratio values for the other cores are generally higher than 10, and do not show any general downcore increase or decrease (Fig. 6).

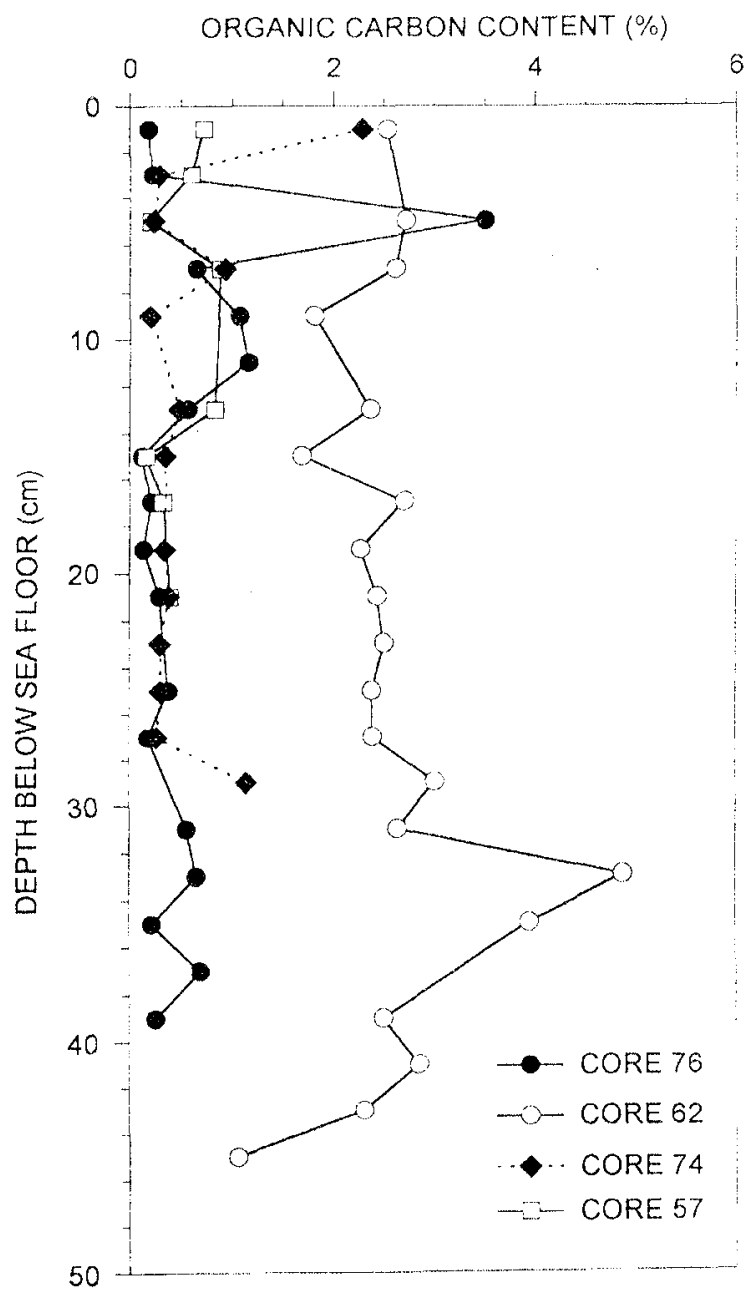

Fig. 4: Variations in organic carbon at various study sites 


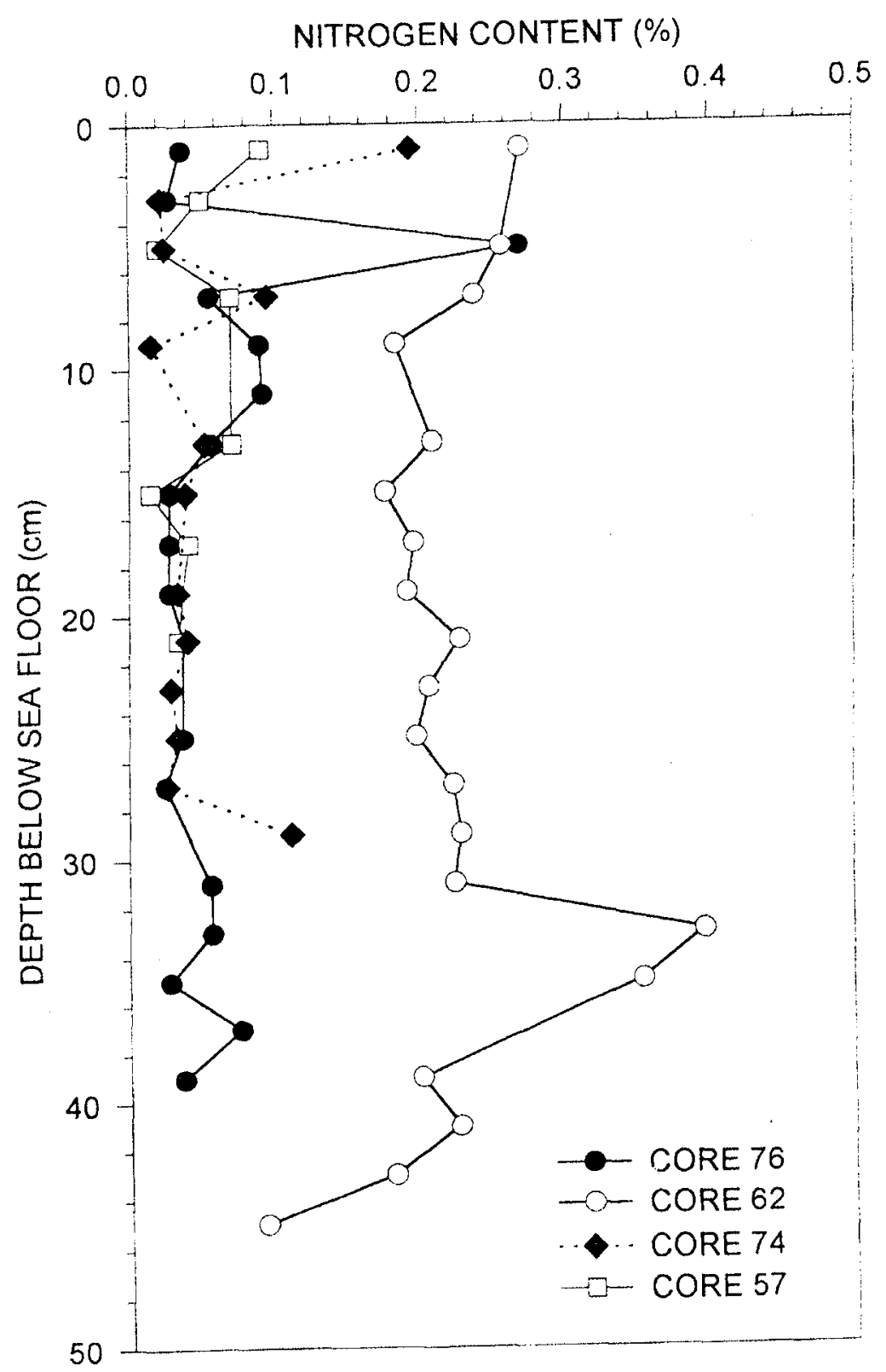

Fig. 5: Down-core variation in the content of nitrogen at different sites 


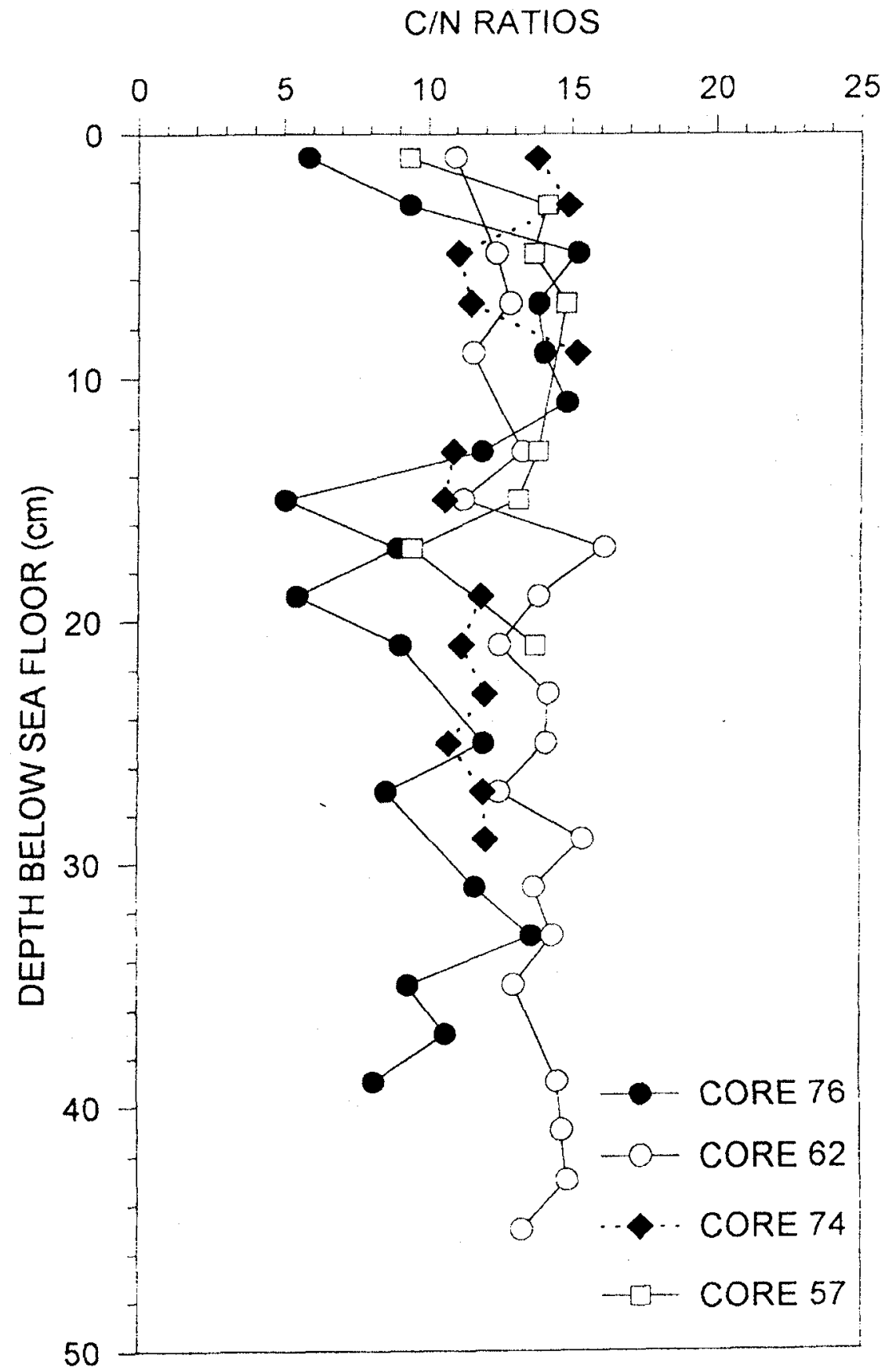

Fig. 6: Down-core variability in $\mathrm{C} / \mathrm{N}$ ratio values at different sea locations off the City of Dar es Salaam, Tanzania 


\section{DISCUSSION}

The stable carbon and nitrogen isotope compositions of OM observed in this study show a slight downcore decrease (Figs. 2 and 3). A similar dowoncore trend in these two parameters has been observed elsewhere (Spiker \& Hatcher 1984, Velinsky et al. 1991, McArthur et al. 1992, Muzuka 1996, Muzuka \& Hillaire-Marcel 1999). Although some workers have suggested absence of alteration of isotope composition in the course of diagenetic alteration of OM (Dean et al. 1986, Sackett 1989, Meyers 1994), others have associated downcore decreases or increases with diagenetic changes (Spiker \& Hatcher 1984, Velisky et al. 1991, McArthur et al. 1992, Muzuka 1996, Muzuka \& Hillaire-Marcel 1999). This is particularly supported by the fact that the stable isotope compositions of various components of organic material such as amino acids, carbohydrate, lignin as well as their quantity and degree towards diagenesis vary (Degens 1969). Therefore, this trend which is associated with a decrease in the contents of OC and nitrogen (Fig. 4 and 5) could be due to diagenetic changes resulting from diagenetic loss of compounds such as amino acids and carbohydrates that are enriched in ${ }^{13} \mathrm{C}$ and ${ }^{15} \mathrm{~N}$ (Degens 1969, Macko et al. 1983, Marco \& Estep 1984). Furthermore, since the C/N ratios of most marine plants is less than 10 (Hedges et al. 1986, Meyers 1994), $\mathrm{C} / \mathrm{N}$ values greater than 10 observed in this study particularly at site WO57 could be a result of preferential loss of nitrogen bearing compounds over that of carbon.

The mean $\delta^{13} \mathrm{C}$ and $\delta^{15} \mathrm{~N}$ values for the black-greasy layers observed at Site WO 76 are $-22 \%$ and $5 \%$, while that of light coloured layers averages $-18 \% 0$ and $5 \%$ respectively (Figs. 2 and 3). Lower ${ }^{13} \mathrm{C}$ values in black-greasy layers relative to the light coloured layers could be a result of mixing between oils and other allochthonous terrestrial material. The stable isotope compositions of $\mathrm{OC}$ for unaltered petroleum have been observed to range from $-34 \%$ to $-18 \%$ and averaging $-28 \%$ (Faure 1986, Hoefs 1987 for review). Other naturally occurring organic materials that have similar isotope values include that of $\mathrm{C}_{3}$ terrestrial material and high latitude phytoplankton (Fontugne \& Duplessy 1978, 1981, Deines 1980, Faure 1986, Hoefs 1987, Rau et al. 1989, Muzuka 1999a). For a shallow coastal tropical waters, where the core was collected, it is unlikely that large component OM was derived from phytoplankton debris, which averages $-20 \%$ in low latitude (Fontugne \& Duplessy 1978, 1981, Deines 1980, Faure 1986, Hoefs 1987, Rau et al. 1989 for review). Because of greasy character it is likely that large component of the material was derived from oils, but definitely mixed with terrestrial $C_{3}$ and $C_{4}$ type of organic material and other organic material derived from the marine environment particularly seagrasses and algae. Because of lack of distinct isotopic compositions between terrestrially derived $\mathrm{C}_{3}$ organic material and petroleum, it is not possible to estimate relative contribution of each source. 
The presence of black-greasy layers further suggests that there is a human influence in the type of material deposited in the area. The black-greasy layers, might have originated from garages and deposited there during rainy seasons where the level of runoff was high.

Lack of differences in the nitrogen stable isotope compositions between blackgreasy and light coloured layers could be a result of similar isotope composition between oil and terrestrial OM. The nitrogen stable isotope compositions for the Tanzanian coastal flora averages 5\% (Muzuka 1999a), a value that might be similar to that of oil. Although no average value has been reported, reported nitrogen stable isotope composition for petroleum range from $0.7 \%$ to $8.3 \%$ (Faure 1986).

Low isotope values at Site WO 62 may be attributed to a significant contribution of allochthonous material in the area. Assuming that the terrestrial end member value is $-28 \%$ (Muzuka 1999a), and that the major contributors of the organic material in the coastal area are seagrasses and macro-algae with a mean isotope value of $-12 \%$ (Gearing 1988), allochthonous contribution in the harbour would be more than $60 \%$.

Reported global nitrogen stable isotope values for terrestrial organic material range from $0 \%$ to $4 \%$ and average 2\% (Létolle 1980, Macko 1981, 1983, Kaplan 1983, Gearing 1988). Thus, elevated values of $15_{\mathrm{N}}$ observed in the Dar es salaam harbour and off Msimbazi river would suggest that contribution of terrestrial material is minimal. However, the stable isotope composition of nitrogen for coastal Tanzanian flora and Amboseli National Park (Kenya) averages 5\% (Muzuka 1999a), suggesting that the material deposited in coastal areas is indeed of terrestrial source. A similar observation of higher stable isotope values for material that reflect high proportion of terrestrial material has been observed else where (Gearing 1988 for review). Therefore, the observed low isotope compositions of $\mathrm{OC}$ in association with high $15_{\mathrm{N}}$ values may still be an indication of anthropogenic input of $\mathrm{OM}$ to the area.

There is inter-site differences in the stable isotope compositions of $\mathrm{OC}$ and nitrogen with a site that is located in the Msasani Bay having the most depleted ${ }^{15} \mathrm{~N}$ and enriched ${ }^{13} \mathrm{C}$. Such a difference could be a result of inequalities in the relative proportion of terrestrial material. As pointed out above, sites located in the Harbour and off Msimbazi river, have relatively high proportion of terrestrial material than in the Msasani Bay. Low input of terrestrial material in the Msasani bay is supported by the work of Fay et al. (1992) who observed lack of $\mathrm{CaCO}_{3}$ dilution just $1 \mathrm{~km}$ off shore indicating that siliciclastic materials are only transported parallel to the shoreline by longshore current. High proportion of autochthonous organic material in the Msasani bay is not derived from phytoplankton which have $\delta^{13} \mathrm{C}$ values that are lower than $-19 \%$, but rather from seagrasses and macro algae. This is 
because, plants that have stable isotope compositions values that are higher than $-16 \%$ include land grasses, seagrasses, algae and coral tissues (Gearing 1988, Yamamuro et al. 1995). Therefore, the observed enrichment in ${ }^{13} \mathrm{C}$ values in the Msasani Bay that averages $-15 \%$ associated with low $15 \mathrm{~N}$ values is probably high proportion of OM derived from seagrasses and macro algae. Lower nitrogen isotope values are due to the fact that synthesized organic material by seagrasses and macro algae result from the utilization of fixed atmospheric nitrogen, which is isotopically not significantly different from that of atmospheric nitrogen $(0 \%)$.

There is a preferential preservation of $\mathrm{OC}$ and nitrogen in the Dar es salaam harbour relative to other sites (Figs. 4 and 5). Preferential preservation could be a result of enhanced primary productivity (Pedersen \& Calvert 1990, Pedersen et al. 1992). However, preferential preservation could also be related to the rate of tidal sediment deposition and removal as well as preferential deposition of more resistant terrestrial material towards diagenesis. Tides in the harbour are asymmetrical with high velocity during flood and lower velocities during ebb periods (Shaghude, personal communication). Such tidal pattern allows preferential deposition of particulate matter in the harbour, and that is why dredging activities need to be carried out regularly. Sedimentation rate has been pointed out as one of the causes of preferential preservation of OM (Canfield 1994). Although data on sedimentation rates in the harbour are lacking, most likely, the harbour is currently experiencing high sedimentation rate owing to the fact that particulate materials are being derived from the surrounding land mass and offshore resulting from asymmetrical tidal current pattern.

\section{CONCLUSION}

The values of stable isotope compositions of OC for sedimentary material preserved in the Msasani Bay is high relative to that deposited off the Msimbazi river and the Dar es salaam harbour. In contrast the Msasani Bay has the lowest stable isotope composition of nitrogen. The observed trend could be due to the fact that organic material preserved in the Msasani Bay is mainly derived from seagrasses and algae, and contribution of this source is high. Owing to the lack of major rivers in the Msasani Bay, capable of transporting significant amounts of land based material, there is little influence of terrestrial OM in the Bay.

Sediments preserved in the Dar es salaam harbour and off the Msimbazi river entrance are characterized by low OC isotope values and high nitrogen isotope values relative to that of the Msasani Bay. Such a difference between the two areas suggest that there is a significant quantity of allochthonous material in the Dar es salaam harbour and off Msimbazi river than in the Msasani Bay. Off the Msimbazi river in particular, human influence is high and material deposited there is of multiple sources. 
Preferential preservation of OM is currently taking place in the Dar es salaam harbour with other areas experiencing high rate of diagenetic alteration of OM. Furthermore, diagenetic alteration of OM may have contributed to a slight downcore decrease in the contents of OC and stable isotope compositions of $\mathrm{OC}$ and nitrogen.

\section{ACKNOWLEDGEMENT}

The author is grateful for the field assistance by E. Edward, A. H. Iddi, and J. Katomanga. I highly appreciate the Department of Zoology and Marine Biology of the University of Dar es salaam for the permission to use their boat. This project was funded by the Intergovernmental Oceanographic Commission of UNESCO through WIOMSA (West Indian Ocean Marine Science Association) and the University of Cape Town through USHEPiA programme.

\section{REFERENCES}

Anderson B, Scalan RS, Behrens EW and Parker PL 1992 Stable carbon isotope variations in sediments from Baffin Bay, Texas, U.S.A.: Evidence for cyclic changes in organic matter source. Chemical Geology 101: 223-233

Behrens EW and Frishman SA 1971 Stable carbon isotopes in blue-green algal mats. Journal of Geology 79: 94-100

Canfield D 1994 Factors influencing organic carbon preservation in marine sediments. Chemical Geology 114: 315-329

Coplen TB 1995 Discontinuance of SMOW and PDB. Nature 375: 285

Dean WE, Arthur MA and Claypool GE 1986 Depletion of ${ }^{13} \mathrm{C}$ in Cretaceous marine organic matter: Source, diagenetic, or environmental signal? Marine Geology 70: 119-157

Degens ET 1969 Biogeochemistry of stable carbon isotopes: In: Englington, G and Murphy MTJ (eds) Organic Geochemistry. Springer Verlag, New York pp: 304-329

Deines ET 1980 The isotopic composition of reduced organic carbon. In: Fritz P and Fontes J-Ch (eds). Handbook of Environmental Isotope Geochemistry. Vol. 1A. Elsevier, New York: pp 329-406

Faure G 1986 Principles of Isotope Geochemistry (2nd Edition). John Wiley \& Sons, New York

Fay M, Masalu DCP and Muzuka ANN 1992 Siliciclastic-carbonate transitions in surface sediments of a back-reef lagoon north of Dar-es-Salaam (Tanzania). Sedimentary Geology 78: 49-57

Flückiger J, Dällenbach A, Blunier T, Stauffer B, Stocker TF, Raynaud D and Barnola J-M 1999 Variations in atmospheric $\mathrm{N}_{2} \mathrm{O}$ concentration during abrupt climatic changes. Science 285: 227-230 
Fontugne MR and Duplessy JC 1978 Organic carbon ratio of marine plankton related to surface water masses. Earth and Planetary Science Letters 41: 365-371

Fontugne MR and Duplessy JC 1981 Organic carbon isotopic fractionation by marine plankton in the temperature range -1 to $30^{\circ} \mathrm{C}$. Oceanologica Acta 4: 85-90

Froelich PN, Klinkhammer GP, Bender ML, Luedtke NA, Heath GR, Cullen D, Dauphin P, Hammond D and Hartman B 1979 Early oxidation of organic matter in pelagic sediments of the eastern equatorial Atlantic: Suboxic diagenesis. Geochimica et Cosmochimica Acta 43: $1075-1090$

Fry B and Sherr EB $1984 \delta^{13} \mathrm{C}$ measurements as indicators of carbon flow in marine and freshwater ecosystems. Contributions to Marine Science 27: 13-47

Gearing JN 1988 The use of stable isotope ratios for tracing the nearshoreoffshore exchange of organic matter. In: Jansson BO (ed.) Lecture Notes on Coastal-Offshore Ecosystem Studies, CoastalOffshore Ecosystem Interactions. Vol. 22. Springer-Verlag, Berlin: pp: 69-101

Hedges JI, Clark WA, Quay PD, Richey JE, Devol AH and Santos UM 1986 Compositions and fluxes of particulate organic material in the Amazon River. Limnology and Oceanography 31: 717-738

Henrichs SM 1992 Early diagenesis of organic matter in marine sediments: progress and perplexity. Marine Chemistry 39: 119-149

Hoefs J 1987 Stable Isotope Geochemistry. Springer-Verlag, London

Kaplan IR 1983 Stable isotopes of sulfur, nitrogen and deuterium in recent marine environments. In: Arthur MA, Anderson TF, Kaplan IR, Veizer $\mathbf{J}$ and Land $L$ (eds) Stable isotopes in sedimentary Geology. SEPM short course No. 10, Dallas: 2-1 - 2-108

Létolle R 1980 Nitrogen-15 in natural environment. In: Fritz P and Fontes JCh (eds) Handbook of environmental isotope geochemistry Vol. IA. Elsevier, New York pp: 407-433

Macko SA 1981 Stable nitrogen isotope ratios as tracer of organic geochemical processes. Ph.D Dissertation, Austin

Macko SA 1983 Source of organic nitrogen in mid-Atlantic coastal bays and continental shelf sediments of the United States: Isotopic evidence. Carnegie Institution Geophysical Laboratory Yearbook 1982/83, Washington

Macko SA and Estep MLF 1984 Microbial alteration of stable nitrogen and carbon isotopic compositions of organic matter. Organic Geochemistry 6: 787-790

Macko SA, Estep MLF, Hare PE and Hoering TC 1983 Stable nitrogen and carbon isotopic composition of individual amino acids isolated from cultured microorganisms. Isotopic evidence. Carnegie Institution Geophysical Laboratory Yearbook, 1982/83, Washington 
McArthur JM, Tyson RV, Thompson J and Mattey D 1992 Early diagenesis of marine organic matter: Alteration of the carbon isotopic composition. Marine Geology 105: 51-61

Meyers PA 1994 Preservation of elemental and isotopic source identification of sedimentary organic matter. Chemical Geology 114: 289-302

Muzuka ANN 1996 Burial rate and diagenetic changes of nitrogen bearing organic matter in the subarctic northwest Atlantic. Ph. D. thesis, Université du Québec à Montréal

Muzuka ANN 1999a Isotopic compositions of tropical East Africa flora and their potential as source indicators of organic matter in coastal marine sediments. Journal of African Earth Sciences 28: 757-766

Muzuka ANN 1999b Stable isotope compositions of sedimentary organic matter off Zanzibar town. Tanzania Journal of Science 25: 55-70

Muzuka ANN and Hillaire-Marcel C 1999 Burial rates of organic matter along the eastern Canadian margin and stable isotope constraints on its origin and diagenetic evolution. Marine Geology 160: 251270

Pedersen TF and Calvert SE 1990 Anoxia vs productivity: What controls the formation of organic-carbon rich sediments and sedimentary rocks?. American Association of Petroleum Geologists Bulletin 74: $454-466$

Pedersen TF, Shimmield GB and Proce NB 1992 Lack of enhanced preservation of organic matter in sediments under the oxygen minimum zone on the Oman Margin. Geochimica et Cosmochimica Acta 56: 545-551

Peters KE, Sweeney RE and Kaplan IR 1978 Correlation of carbon and nitrogen stable isotope ratios in sedimentary organic matter. Limnology and Oceanography 23: 598-604

Rau GH, Takahashi T and Des Marais DJ 1989 Latitudinal variations in plankton $\delta^{13} \mathrm{C}$ : Implications for $\mathrm{CO}_{2}$ and productivity in past ocean. Nature 341: $516-518$

Sackett WM 1989 Stable carbon isotope studies on organic matter in marine environment. In: Fritz $\mathrm{P}$ and Fontes J-Ch (eds) Handbook of Environmental Isotope Geochemistry Vol. 1I. Elsevier, New York pp: $139-169$

Schelske CL and Hodell DA 1995 Using carbon isotopes of bulk sedimentary organic matter to reconstruct the history of nutrient loading and eutrophication in Lake Erie. Limnology and Oceanography 40: 918-929

Spiker EC and Hatcher DF 1984 Carbon isotope fractionation of sapropelic organic matter during early diagenesis. Organic Geochemistry 6 283-290

Sweeney RE and Kaplan IR 1980 Natural abundances of $15^{N}$ as a source indicator for near-shore marine sedimentary and dissolved nitrogen. Marine Chemistry 9: 81-94 
Sweeney RE, Khalil EK and Kaplan IR 1980 Characterization of domestic and industrial sewage in southern California coastal sediments using nitrogen, carbon, sulfur and uranium traces. Marine and Environmental Research 3: 225-243

Tissot BP 1984 Petroleum Formation and Occurrence: A New Approach to Oil and Gas Exploration 2nd edition. Springer-Verlag, Berlin

Velinsky DJ, Burdige DJ and Fogel ML 1991 Nitrogen diagenesis in anoxic marine sediments: Isotope effects. Geophysical Laboratory, Carnegie Institution Year Book 1990/91: 154-162

Watson RT, Rodhe H, Oescheger H, Seigenthaler U 1990 Greenhouse gases and aerosols. In: Houghton JT, Jenkins GJ and Ephraums JJ (eds) Climate Change-the IPCC Scientific Assessment. Cambridge University Press, Cambridge

Yamamuro M, Kayanne H and Minagawa M 1995 Carbon and nitrogen stable isotopes of primary producers in coral reef ecosystems. Limnology and Oceanography 40: 617-621 